\title{
Perception of the Role of the Nigeria Police Force in Militating Against Kidnapping Activities in Ubiaja Community of Edo State
}

\section{Ogini Wilson Onaivi}

Department of Sociology \& Psychology, Faculty of Social Science, Delta State University, Abraka, Delta State, Nigeria

\section{Email address:}

wilsonaivi@gmail.com

\section{To cite this article:}

Ogini Wilson Onaivi. Perception of the Role of the Nigeria Police Force in Militating Against Kidnapping Activities in Ubiaja Community of Edo State. International Journal of Education, Culture and Society. Vol. 5, No. 4, 2020, pp. 70-78. doi: 10.11648/j.ijecs.20200504.12

Received: June 14, 2020; Accepted: July 2, 2020; Published: July 28, 2020

\begin{abstract}
This study examined perception of the Nigerian Police Force in militating against kidnapping activities in Ubiaja Community of Edo State, Nigeria. The ex-post-facto research design was adopted, using survey method to elicit primary data and using the chi-square statistical technique for the analysis of data and testing of hypotheses formulated for the study. The study adopted the conflict theory to examine and explain the variables of peoples' perception of the Nigerian Police Force on the curbing of the menace of kidnapping in Nigeria. The study revealed a positive relationship between inadequate funding, training and cases of corruption and the people's perception of lack of capacity to curb kidnapping menace in Ubiaja Community in Edo State. Among other things, the study recommends internal rebirth in the structure and workings of the Nigeria Police Force to get rid of corruption within the rank and file of the Force. Government should also ensure adequate funding of the Police Force to make funds available to train and re-train the police; thereby equipping them with state of Art gadgets to satisfactorily combat the menace of kidnapping in Ubiaja Community and by extension, Nigeria in general.
\end{abstract}

Keywords: Conflict, Kidnapping, Nigeria Police Force, Funding, Public, Perception

\section{Introduction}

Nigeria as of late has seen a phenomenal degree of frailty. Beland, sees insecurity as "the state of fear or anxiety stemming from a concrete or alleged lack of protection [1]." A typical example of insecurity is kidnapping. Kidnapping for ransom in Nigeria has been on the rapid increase over the years and there appears to be no end to this extremely bad practice despite the existence of a police force whose statutory function is targeted at crime detection and control. Kidnapping scenario has remained one of the contemporary social menaces plaguing the Nigerian society today. The expanding development of kidnapping activities in Nigeria has become a serious danger to national harmony and security. It has influenced the image of the nation and has eaten profoundly deep into each area and section of the country's economy.

Kidnapping can be seen as false imprisonment involving the illegal confinement of individuals against his or her own will by another individual in such a way as to violate the a person's entitlement to be liberated from the limitation of development and movement. Obarisiagbon [2], conceived kidnapping as the unlawful taking away of an individual without his consent and keeping the person in a confined place until a ransom is paid. Kidnapping involves an act of seizing, obtaining, removing and keeping an individual in care either forcibly or extortion [3]. It is a crime and social malady that has made the Nigerian security environment to be complex. As indicated by Davidson [4], a gathering of criminals furnished with firearms and mobile phones capture clueless casualties and drag their casualty into an isolated spot and start to make calls to whomever and interest for a payoff.

The kidnapper erratically engages in criminality for several complex reasons ranging from unemployment, idleness, vengeance, rituals, and monetary gains to political reasons [5]. Inyang, affirmed that involvement in kidnapping activities is as a result of a multiplicity of factors linked to poverty, the get rich quick syndrome, greed, peer group influence, unemployment and moral decadence [6]. 
Obarisiagbon, believes that the explanation behind the ascent in kidnapping is to be situated at the passageway of the Nigeria Police Force [2]. Similarly, Okarah [7] affirmed that corruption and dishonesty are endemic among the rank and file of the police force. In other words, the kidnapping situation and the seemingly lack of willpower by the police to enforce the law seem to have made Nigerians resign to their fate.

Kidnapping is a severe offence which denies the casualty of his/her freedom. The incidence of the unlawful and nonconsensual taking of a person with the intent of demanding ransom before victims are being released is a crime punishable under section 364 of the Criminal Code, [8] with ten years imprisonment [9]. However, recently, some states like Anambra, Edo and Delta considering the alarming rate of kidnapping, enacted law by making kidnapping an offence punishable by death. In spite of this, kidnapping is still on the increase. This has made researchers to turn their attention on the job and elements of the Nigeria police in wrongdoing identification, anticipation and prevention.

The Nigerian Police force was established between 1867 and 1914 to maintain what the colonialists felt was law and order [10]. At first, two kinds of police framework viz force and constabulary were formed and managed by the colonial authorities and the neighborhood forces which were managed by the nearby conventional traditional rulers. Today, the Nigeria police force has undergone organizations and reorganizations with the Police Act clearly stating their functions as to detection of crime, protection of lives and property of residents, support of peace in the general public, examination of issues relating to wrongdoing and capture, and arraignment of guilty parties in the law court [11]. Thus, formal policing as the name infers is seen by; Etannibi, Alemika, and Innocent [12]; Inyang and Ubong [13] as government possessed or legally affirmed organizations responsible for security.

Various factors have been blamed as constituting challenges to effective and efficient policing in Nigeria such as; widespread corruption among the police force, taking of bribe from suspects, inadequate training, materials and poor remuneration for both officers and men of the Nigeria police force emanating from inadequate funding. Odekunle [14] noted that, in spite of the empowering legal sponsorship that the police have, it has rather shown and created a lot of discussions with respect to controlling the danger of kidnapping. Ugwuoke, [15] noted with regrets that the more the police try to strategize on ways and methods of tracking down the kidnappers, the more they unleash terror and mayhem on their victims and the society.

\subsection{Statement of the Problem}

To state that kidnapping is a hazard in contemporary Nigeria is without a doubt a modest representation of the truth. The rise in the wrongdoing of capturing in Nigeria remains the most upsetting, squeezing, pervasive and risky issue which has decreased man into similarity to a creature. Victims of kidnapping suffer psychological trauma from the loss of freedom and dignity. The emergence of kidnapping has however be blamed on several factors such as; government inability to address the root causes of dissatisfaction, anger and agitation among various groups in the country (militancy), proliferation of arms and military uniform, poverty, unemployment, greed, corruption and the poor government, inadequate control of our water ways and terrestrial boundaries, in addition to the loss of the patriarchal moral authority and issues bothering on the enforcement of existing law and order regulating kidnapping activities. In this has in so many ways it undermines the quality of life of the Nigerian citizens because it leads to serious problems such as poor health status, infrastructural decay and negative perception of Nigeria at local, state, national and global scene. It is in the light of the above situation that this paper seeks examined the perception of the function of the Nigeria Police in militating against kidnapping activities in Ubiaja community of Edo State.

Purpose of the Study

The broad objective of this study is to evaluate perception of the role of the Nigerian Police Force and curbing of the menace of kidnapping in Ubiaja Community, Edo State. Based on this objective the following research questions were generated:

i. What impact does funding have towards improving the role of the Nigerian Police Force in curbing the menace of kidnapping?

ii. Does inadequate training have any influence on the role of the Nigerian Police Force in curbing the menace of kidnapping?

iii. To what extent does corruption influence the role of the Nigerian Police Force in curbing the menace of kidnapping?

\subsection{Research Hypotheses}

The following null hypotheses were formulated in this study

i. There is no significant difference between the impact of funding and the role of the Nigerian Police Force in curbing the menace of kidnapping.

ii. There is no significant difference between the influence of inadequate training and the role of the Nigerian Police Force in curbing the menace of kidnapping.

iii. There is no significant difference between the influence of corruption and the role of the Nigerian Police Force in curbing the menace of kidnapping.

\subsection{Significance of the Study}

This study, being an exploration of perception on the violent crime of kidnapping which is currently a global menace that has kept many residents in Ubiaja Community, Edo State without sleep, will be of enormous significance to the society including male and female, young and old by better exploring their perception towards kidnapping, especially since it is explored from a holistic perspective. It is hoped that this research would aid the various levels of government, policy experts and analysts in grasping the impacts of kidnapping. It will prompt the need for community input to policing and 
crime management in Ubiaja community which threatens its security values and overall progress. The essentialness of the occasion lies in its capability to electrify network support and secure residents' assent for the Nigeria Police in progression of criminality prevention and mandate to apprehend and prosecute perpetrators of crime.

\section{Review of Related Literature \& Theoretical Framework}

\subsection{Literature Review}

Nigeria has refracted to a playing ground of savagery, fretfulness, strict viciousness and relentless capturing which debilitate numerous individuals to have trust in better Nigeria or to have faith in guaranteed changed. Ugwuoke [15] opted that, the degenerate impact of Nigerian pioneers more likely than not assumed a noteworthy job in the heightening of indecencies, for example, seizing. Adibe, [16] argued that defilement among the Nigerian Police Force and government officials contributes colossally to capturing in Nigeria. In reality, an instance of abducting was supposed to be planned by a high positioned cop who feels that he is exempt from the laws that apply to everyone else; Olebera as cited in Ugwulebo, [15]. Eso, as cited in Nwadiorah and Nkwocha, [17] recognized hostage-taking to be inclusive of kidnapping.

According to Eso, kidnapping means to seize and detain unlawfully a person by force and fraud and to remove a person to an undisclosed location against his will and usually for hostage or to obtain ransom. It had also been noted that kidnappers belong to common criminal terrorist and common criminal terrorist are motivated by gains [18]. Ugwuoke [15], in his studies found that many unemployed youths in Nigeria are poverty stricken and usually find solace in criminal activities which of course, include participation in kidnapping. In addition, Diara [19], asserts that kidnapping in Nigeria is a kind of social revolution by the youths especially the unemployed ones who are not satisfied with their 24 socio-economic lots. Different authorities have perceived kidnapping to be a rising incidence as a result of the high rate of unemployment in Nigeria $[6,16]$.

Numerous reasons can equally be attributed to the causes of kidnapping in Nigeria. Researchers like Inyang and Ubong [13, 20, 21, 22, 23]. Essien and Ema [22] gave the following reasons to be connected to the predominance of kidnapping activities in Nigeria; militancy, proliferation of arms and military uniform, poverty, unemployment, moral decadence and quest to get rich quick syndrome, greed, corruption and the poor government, inadequate control of our sea territorial jurisdiction, statelessness and normlessness of Nigeria state, loss of the patriarchal moral authority and problems with law enforcement.

The inefficiency of the Police regarding the maintenance of law and order became glaring as cases of armed robbery involving the use of sophisticated weapons and high casualties as well as incidents of ethno-religious conflicts persisted. Thus, illegally held guns are increasingly being used by outlaws to commit violent crimes of kidnapping and robbery in many places in Nigeria. Security of life and property are of the main role of government. 1999 Constitution accentuate that the security and government assistance of the individuals will be the main role of the administration". There is no uncertainty that the spate of instability in the nation is disturbing. There are a few security challenges which cut over the alcoves and corners of the nation [24].

Lacking preparing, materials and poor compensation for the two officials and men of the Nigeria police power are eminent elements that have made appalling execution for the police in completing their legal elements of wrongdoing avoidance and discovery. The preparation of police officers is a sine qua non to compelling execution however unfortunately, there is nearly nothing or none directly and where any exist, it is poor as the men are not completely presented to current policing [25]. The elements of the Nigerian Police Force are expressed in the Police Act. The Police Act accommodates the association, control, forces and obligations of the Police in Nigeria.

The general duties of the Police are: prevention and detection of crime, apprehension of offenders, preservation of law and order, protection of life and property, in addition, due enforcement of all laws and regulations with which they are directly charged and also the performance of such military duties within or outside Nigeria as may be required of them by the Police Act or any other Act. The role of the Nigerian Police force in curbing kidnapping cannot be overestimated. Odekunle, [14] gives three points that when considered, it will make it becomes clearer. The Nigeria Police Force the constituted authorities generally empowered to abate crime both incidentally and procedurally, thus, they are the main figures in the prevention of crime and enforcers of the processes of law and order in the land.

\subsection{Theoretical Framework}

The mandate of protecting lives and property in most societies is the exclusive function of the police force. This structures' the significant fundamental tenet of the two theories adopted for this study; the conflict resolution theory and social control theory.

\subsubsection{Conflict Resolution Theory (CRT)}

The goal of conflict resolution is perceived as the strategies and procedures engaged with encouraging the tranquil closure of contention and retaliation. Committed group of individuals endeavor to resolve conflicts by effectively imparting information about conflicting motives or ideologies to the rest of the group (e.g., goals; explanations behind holding certain convictions) and by participating in aggregate arrangement. Measurements of the goals of resolution ordinarily parallel components of conflicts in the manner conflict are processed. Cognitive resolution is the manner in which disputants comprehend and see the contention, with convictions, points of view, understandings and perspectives. Emotional resolution is 
standing out disputants feel about a conflict, the enthusiastic vitality. Behavioral resolution is reflective of how the disputants demonstrate their conduct.

Ibeanu [26] showed that harmony is a procedure including exercises that are legitimately or in a roundabout way connected to expanding advancement and reducing conflict. The way toward improving the conditions, wherein the populace lives; normally lessens the development of conflict in that condition henceforth, decreasing components that advance kidnapping activities; like joblessness, destitution, ignorance, ravenousness, poverty, poor security organize, degenerate majority rule government and cultural rot. It is this procedure perspective on harmony that would bring forth strong and feasible harmony, which would deal with the spate of kidnapping incidence in the Nigerian state

\subsubsection{Social Control Theory (SCT)}

Social Control Theory was propounded by the American criminologists, Travis Hirsch in the late 1960s. To him, criminal behaviour and delinquency results from failure of individuals to bond with conventional social groups such as the family and schools. As indicated by Travis Hirsch no exceptional powers were important to clarify law-breaking. Lawbreaking is regularly the most prompt wellspring of satisfaction or compromised conflict resolution, and no unique inspiration is required to clarify such conduct. Human beings are active, flexible organisms who will engage in a wide range of activities, unless the range is limited by processes of socialization and social learning [27]. The neighbourhood mechanisms that reduce crime and disorder include residents' social ties and the degree to which people exercise social control in their neighbourhoods. These ties may build inhabitants' ability to participate in social authority over people in the network, hence diminishing kidnapping activities. The SCT can either be formal or informal.

Formal control may be significant by directly influencing criminality and disorder as well as by impacting residents' informal control practices. Formal social control includes the criminal justice system involving the police, courts and prisons while informal social control consists of mechanisms which are not based upon formal rules but are carried by the family, friends and member of the society on daily basis. Ugwuoke, [15] opined that due to lack of control mechanism corruption seems like it is a tradition in Nigeria. However, the emergence of kidnapping could be seen as a result of poor control mechanism, since communities have no or little control mechanism to fight crime.

\section{Methods and Materials}

\subsection{Research Design}

The research design adopted for any investigative is highly dependent on the nature of the problem that prompted the study. Hence, this study adopted descriptive survey design method as it employs a cross sectional design. Descriptive survey design aims primarily at collecting data and systematically describing the characteristics or features about a given population. The rationale for choosing this design is that, it is the most appropriate design suitable in exploring the perception of the role of the Nigerian Police Force and curbing of the menace of kidnapping in Ubiaja Community, Edo State.

\subsection{Population of the Study}

The population of this study is made up of Police officers, legal practitioners, kidnap victims and civil servants. The study was conducted in Ubiaja Community, Edo State. Hence, the overall target population for this study is 2,309 respondents.

\subsection{Sample and Sampling Techniques}

In this study, the estimated population size is 2,309 . The sample size was determined at 5\% error tolerance and 95\% degree of confidence, using the Yamane's formula as shown below:

$$
\mathrm{n}=\frac{\mathrm{N}}{1+\mathrm{N}(\mathrm{e})^{2}}
$$

Where: $\mathrm{n}=$ Sample size, $\mathrm{N}=$ Population, $\mathrm{e}=$ error tolerance and $\mathrm{I}=$ Constant. Since, $\mathrm{n}=2,309, \mathrm{e}=5 \%$ or 0.05 . Hence, the sample size selected for this is 341 using the above formula. Meanwhile, this research work used the random sampling techniques which allowed every respondents an equal and independent opportunity of being included in the sample without bias.

\subsection{Research Instrument}

The researcher used questionnaire in eliciting responses from the respondents. The questionnaire was titled: "Perception of Police Role in Curbing the Menace of Kidnapping Questionnaire (PPPRCMKQ)" and consisted of two major parts. Part one elicited demographic information from the respondents while part two covered multiple choice questions directed to sort perception of the role of the Nigerian Police Force and curbing of the menace of kidnapping in Ubiaja Community, Edo State. Each column of constraints is Likert scaled 5, 4, 3, 2, 1, corresponding to Strongly Agreed, Agreed, Undecided, Disagreed and Strongly Disagreed. Respondents were requested to indicate their responses with tick of good $(\sqrt{ })$ against options of their choice.

\subsection{Data Collection and Statistical Analysis}

Out of a total of 341 copies of the questionnaire administered to the respondents, 150 were completely retrieved. The collected data were analyzed using SPSS statistical tools version 20 to obtain average mean, percentages, frequency and standard deviation. Items with mean value of 3.00 or above were accepted while items with mean value of $<3.00$ were rejected. The formulated hypotheses were tested using chi-square statistical technique at $p$-value $<0.05$ level of significance. 


\section{Results}

\subsection{Demographic Variable}

Table 1. Sex distribution of respondent.

\begin{tabular}{lll}
\hline Gender (Sex) & Frequency & Percentage (\%) \\
\hline Male & 87 & 58 \\
Female & 63 & 42 \\
Total & 150 & 100 \\
\hline
\end{tabular}

The sex of respondents that participated in this study are shown in Table 1 above. The male respondents were 87 (58\%) while the female respondents were $63(42 \%)$. This shows that the male respondents were more than females.

Table 2. Age distribution of respondent.

\begin{tabular}{lll}
\hline Age (years) & Frequency & Percentage (\%) \\
\hline $18-27$ & 24 & 16 \\
$28-37$ & 45 & 30 \\
$38-47$ & 52 & 34.7 \\
48 and above & 29 & 17.3 \\
Total & 150 & 100 \\
\hline
\end{tabular}

Table 2 shows the age group of respondents, it was obtained that $24(16 \%)$ are within the age of $18-37$ years, $45(30 \%)$ are within the age of $28-37,52(34.7 \%)$ are within the age $38-47$ years while $29(17.3 \%)$ are with the age of 48 and above. The result thus shows that most of the respondents fall within the age brackets of $28-47$ years.

Table 3. Educational qualification of respondents.

\begin{tabular}{lll}
\hline Educational Qualification & Frequency & Percentage (\%) \\
\hline FSLC & 11 & 7.3 \\
WASCE/SSCE/GCE & 28 & 18.7 \\
NCE/OND & 56 & 37.3 \\
HND/B.A/B.Sc. and above & 40 & 26.7 \\
Others & 15 & 10 \\
Total & 150 & 100 \\
\hline
\end{tabular}

Table 3 shows the level of highest qualification of respondent. The result shows that $11(7.3 \%)$ had first school leaving certificates, 28 (18.7\%) had WASCE/SSCE/GCE certificates, 56 (37.3\%) had HND/B.A/B.Sc. and above degree(s) while the remaining $15(10 \%)$ had other qualifications. Thus, most of the respondents are degree holders.

Table 4. Occupation of respondents.

\begin{tabular}{lll}
\hline Occupation & Frequency & Percentage (\%) \\
\hline Legal practitioners & 21 & 14 \\
Police officers & 66 & 44 \\
Kidnap victims & 45 & 30 \\
Civil servants & 18 & 12 \\
Total & 150 & 100 \\
\hline
\end{tabular}

Table 4 shows the occupational distribution of the respondents. The result shows that there are $21(14 \%)$ were legal practitioners, $66(44 \%)$ are police officers, $45(30 \%)$ are Kidnap victims while the remaining 18 (12\%) of the respondents represents civil servants.

Table 5. Level of satisfaction with the police performance towards curbing kidnapping.

\begin{tabular}{lll}
\hline Level of satisfaction & Frequency & Percentage (\%) \\
\hline Not At All & 75 & 50 \\
Not Very Satisfied & 50 & 33.3 \\
Fairly Satisfied & 21 & 14 \\
Very Satisfied & 4 & 2.7 \\
Total & 150 & 100 \\
\hline
\end{tabular}

Table 5 shows the level of satisfaction of the public with the police performance towards curbing kidnapping. The level of not satisfied at all with the police performance was $75(50 \%)$, the level of not very satisfied was 50 (33.3\%), while 21 (14\%) confides that they were fairly satisfied and the remaining 4 $(2.7 \%)$ accepted that there were very satisfied with the police performance towards curbing kidnapping

\subsection{Answering of Research Questions}

The three (3) research questions formulated in this study are analyzed as follows:

Research Objective I:

What impact does funding have towards improving the role of the Nigerian Police Force in curbing the menace of kidnapping?

Table 6. Impact of funding towards improving the role of the Nigerian Police Force in curbing the menace of kidnapping.

\begin{tabular}{|c|c|c|c|c|}
\hline $\mathbf{S} / \mathbf{N}$ & Statement & Mean (x) & Std. & Remark \\
\hline 1 & There has been adequate funding of Nigerian police force by government to fight kidnapping in Nigeria & 2.60 & 0.2 & Rejected \\
\hline 2 & Funding has great impact on the performance of the police in relation to reducing kidnapping & 4.28 & 1.1 & Accepted \\
\hline 3 & The poor salary of the Nigerian police has effect on their role in curbing the menace of kidnapping & 3.97 & 1.0 & Accepted \\
\hline 4 & Inadequate welfare of the Nigerian police has impact on their role towards curbing kidnapping & 4.37 & 1.3 & Accepted \\
\hline 5 & Issues of funding affects the equipment and materials used by Nigerian police in curbing kidnapping & 3.71 & 0.8 & Accepted \\
\hline 6 & The state of preparedness of the police to carry out its role of curbing kidnapping is affected by limited funding & 3.71 & 0.8 & Accepted \\
\hline 7 & Mismanagement of funds by government affects the Police role in curbing the menace of kidnapping & 3.62 & 0.8 & Accepted \\
\hline 9 & Inadequate funding is a major problem contributing to alarming rate of kidnapping & 3.80 & 0.9 & Accepted \\
\hline 10 & Financing community policing has great impact on the role of the police in curbing kidnapping & 3.47 & 0.7 & Accepted \\
\hline \multicolumn{2}{|r|}{ Grand Mean } & 3.78 & & Adopted \\
\hline
\end{tabular}

Table 6 shows the average mean and standard deviation of the responses made by the respondents on the impact of funding towards improving the role of the Nigerian Police
Force in curbing the menace of kidnapping. It is shown that out of the 10 items formulated, item $2,3,4,5,6,7,8,9$ and 10 respectively had a mean value of 3.0 and above the 
benchmark and was accepted. However, only item 1 had a mean below the bench mark of 3.0 and was rejected. Meanwhile, the grand mean obtained was 3.78; this implies that majority of the respondents adopted the fact that funding has impact towards improving the role of the Nigerian Police Force in curbing the menace of kidnapping in Ubiaja Community, Edo State. This finding is similar with that of Inyang, [6] and Obarisiagbon and Omagie, [28] who asserted that there has been the underfunding of government agencies in Nigeria, and thus the Nigeria police force specifically in combating criminality.

Research Question II:

Does inadequate training have any influence on the role of the Nigerian Police Force in curbing the menace of kidnapping?

Table 7. Influence of inadequate training on the role of the Nigerian Police Force in curbing the menace of kidnapping.

\begin{tabular}{|c|c|c|c|c|}
\hline $\mathbf{S} / \mathbf{N}$ & Statement & Mean (x) & Std. & Remark \\
\hline 11 & Promotes unfairness and impartiality in kidnapping cases & 3.69 & 0.8 & Accepted \\
\hline 12 & Encourages lack of team work and commitment towards curbing kidnapping reports & 4.47 & 1.3 & Accepted \\
\hline 13 & Promotes negligence of duties among members of the Nigerian Police Force & 3.79 & 0.9 & Accepted \\
\hline 14 & Inability to cope with the trend of crime associated with kidnapping & 3.84 & 0.9 & Accepted \\
\hline 15 & Inability of the police to follow up incidence of kidnapping & 3.71 & 0.8 & Accepted \\
\hline 16 & Enables the police to know appropriate pattern of behavior for various situations & 2.57 & 0.4 & Rejected \\
\hline 17 & Promotes trust and confidence between the people and police & 2.92 & 0.5 & Rejected \\
\hline 18 & Poses serious security threat to the lives of the people & 3.79 & 0.9 & Accepted \\
\hline 19 & Results to lack of skills on how to avoid attack on the Nigerian police force & 3.86 & 1.0 & Accepted \\
\hline 20 & Reduces the professionalism of the police in combating crime & 3.52 & 0.7 & Accepted \\
\hline \multicolumn{2}{|r|}{ Grand Mean } & 3.62 & & Adopted \\
\hline
\end{tabular}

Table 7 shows the average mean and standard deviation of the responses made by the respondents on the influence of inadequate training on the role of the Nigerian Police Force in curbing the menace of kidnapping. It was obtained that out of the 10 items generated; item 11, 12, 13, 14, 15, 18, 19 and 20 respectively had a mean value of 3.0 and above the benchmark and was accepted. However, item 16 and 17 had a mean below the bench mark of 3.0 and was rejected. Meanwhile, the grand mean obtained was 3.62; this implies that majority of the respondents adopted the fact that inadequate training has influence on the role of the Nigerian
Police Force in curbing the menace of kidnapping in Ubiaja Community, Edo State. This finding agrees with the research outcome of Odekunle [14] and Adegoke, [25] who pointed out that there is little or none presently and where any exist, it is very poor as the men are not thoroughly exposed to modern policing resulting in abysmal performance of the Nigeria Police Force in carrying out their statutory role of prevention and detection of crime.

Research Questions III:

To what extent does corruption influence the role of the Nigerian Police Force in curbing the menace of kidnapping?

Table 8. The extent to which corruption influence the role of the Nigerian Police Force in curbing the menace of kidnapping.

\begin{tabular}{|c|c|c|c|c|}
\hline $\mathbf{S} / \mathbf{N}$ & Statement & Mean (x) & Std. & Remark \\
\hline 21 & Emphasis on infrastructural deficiency & 4.22 & 1.2 & Accepted \\
\hline 22 & Emphasis on lack of sophisticated and modern equipment & 3.84 & 0.9 & Accepted \\
\hline 23 & Emphasis on abetting of vices and shielding 'connected' criminals from justice & 4.14 & 1.1 & Accepted \\
\hline 24 & Emphasis on social unrest & 4.40 & 1.2 & Accepted \\
\hline 25 & Emphasis on insurgences & 4.01 & 1.0 & Accepted \\
\hline 26 & Emphasis on threat to property & 4.07 & 1.0 & Accepted \\
\hline 27 & Emphasis on murder cases & 3.96 & 1.0 & Accepted \\
\hline 29 & Emphasis on embezzlement of public funds & 4.19 & 1.1 & Accepted \\
\hline 30 & Emphasis on breakdown of law and order in Society & 3.91 & 0.9 & Accepted \\
\hline \multicolumn{2}{|r|}{ Grand Mean } & 4.06 & & Adopted \\
\hline
\end{tabular}

Table 8 shows the average mean and standard deviation of the responses made by the respondents on the extent to which corruption influence the role of the Nigerian Police Force in curbing the menace of kidnapping. It was obtained that all the 10 items generated; 21, 22, 23, 24, 25, 26, 27, 28, 29 and 30 respectively had a mean value of 3.0 and above the benchmark and was accepted. More so, the grand mean obtained was 4.06; this implies that majority of the extent to which corruption influence the role of the Nigerian Police Force in curbing the menace of kidnapping Ubiaja in Community, Edo State to a high extent. The finding from this study agrees with the works of Onyeozili [29], Odekunle
[14]; Obarisiagbon and Omagie, [28] who have argued that perception of the police is very low due to their abysmal performance oat curbing crime, kidnapping inclusive and that there are myriads of obstacles militating against the efforts of the police in curbing kidnapping activities in Nigeria.

\subsection{Testing of Hypotheses}

For the test of hypotheses to be accurate and complete, the researcher also made use of the Chi- square goodness of fit test, as Obasi (2008) pointed out that "researchers use the Chi-square $\left(\mathrm{X}^{2}\right)$ test when they wish to compare an actual observed distribution." The general formula for Chi-square 
computation is thus: $\mathrm{X}^{2}=(0-\mathrm{E})^{2} / £$

Where; $0=$ Observed frequency

$\mathrm{E}=$ Expected frequency

$£=$ "Sum of" items

$\mathrm{X}^{2}=$ Chi-square
Null Hypothesis I:

There is no significant difference between the impact of funding and the role of the Nigerian Police Force in curbing the menace of kidnapping.

Table 9. Chi-Square Statistic to Hypothesis I.

\begin{tabular}{|c|c|c|c|c|c|}
\hline Variables & Observed Frequency (0) & Expected frequency (E) & 0-E & $(0-E)^{2}$ & $(0-E)^{2} E$ \\
\hline Strongly agree & 57 & 30 & 27 & 729 & 23.5 \\
\hline Agree & 55 & 30 & 25 & 625 & 20.2 \\
\hline Undecided & 1 & 30 & -29 & 841 & 27.1 \\
\hline Disagree & 25 & 30 & -5 & 25 & 0.8 \\
\hline Strongly disagree & 12 & 30 & -18 & 324 & 10.5 \\
\hline Total & 150 & & & & 82.1 \\
\hline
\end{tabular}

From Table 9 above, using K- 1 under the probability level table, we have $5-1=4$. Using 0.05 level of significance, our table value is therefore 9.488. Since the calculated value of 82.1 is greater than the table value of 9.488 , we can now accept the alternative hypotheses $\left(\mathrm{H}_{1}\right)$. Therefore, we conclude that there is significant difference between the impact of funding and the role of the Nigerian Police Force in curbing the menace of kidnapping.

Test of Hypothesis II:

There is no significant difference between the influence of inadequate training and the role of the Nigerian Police Force in curbing the menace of kidnapping.

Table 10. Chi-Square Statistic to Hypothesis II.

\begin{tabular}{llllll}
\hline Variables & Observed Frequency (0) & Expected frequency (E) & $\mathbf{0 - E}$ & $\mathbf{( 0 - E )}^{\mathbf{2}}$ & $\mathbf{( 0 - E )}^{\mathbf{2}} \mathbf{E}$ \\
\hline Strongly agree & 60 & 30 & 30 & 900 & 29.0 \\
Agree & 45 & 30 & 15 & 225 & 7.3 \\
Undecided & 2 & 30 & -28 & 784 & 25.3 \\
Disagree & 24 & 30 & -6 & 36 & 1.2 \\
Strongly disagree & 19 & 30 & -11 & 121 & 3.9 \\
Total & 150 & & & & 66.6 \\
\hline
\end{tabular}

Based on the hypothesis II testing as shown in Table 10 above, using K- 1 under the probability level table, we have 5 $-1=4$. Using 0.05 level of significance, our table value is therefore 9.488. Since the calculated value of 66.6 is greater than the table value of 9.488 , we can now accept the alternative hypotheses $\left(\mathrm{H}_{1}\right)$. Therefore, we conclude that there is significant difference between the influence of inadequate training and the role of the Nigerian Police Force in curbing the menace of kidnapping.

Test of Hypothesis III:

There is no significant difference between the influence of corruption and the role of the Nigerian Police Force in curbing the menace of kidnapping.

Table 11. Chi-Square Statistic to Hypothesis III.

\begin{tabular}{|c|c|c|c|c|c|}
\hline Variables & Observed Frequency (0) & Expected frequency $(\mathrm{E})$ & 0-E & $(0-E)^{2}$ & $(0-E)^{2} E$ \\
\hline Strongly agree & 65 & 30 & 35 & 1225 & 39.5 \\
\hline Agree & 52 & 30 & 22 & 484 & 15.6 \\
\hline Undecided & 2 & 30 & -28 & 784 & 25.3 \\
\hline Disagree & 24 & 30 & -6 & 36 & 1.2 \\
\hline Strongly disagree & 7 & 30 & -23 & 529 & 17.1 \\
\hline Total & 150 & & & & 98.6 \\
\hline
\end{tabular}

Table 11 above shows the testing of hypothesis III, hence, using K- 1 under the probability level table, we have $5-1=4$. Using 0.05 level of significance, our table value is therefore 9.488. Since the calculated value of 98.6 is greater than the table value of 9.488 , we can now accept the alternative hypotheses $\left(\mathrm{H}_{1}\right)$. Therefore, we conclude that there is significant difference between the influence of corruption and the role of the Nigerian Police Force in curbing the menace of kidnapping.

\section{Conclusion and Recommendations}

This study examined perception of the role of the Nigerian
Police Force and curbing of the menace of kidnapping in Ubiaja Community, Edo State. The findings from the study maintained that kidnapping for ransom has been on the increase in the study area and there appears to be no end in sight despite the presence of a police power whose legal capacity of detection and prevention of crime has experienced harsh criticism for its appalling execution. The study found that there has not been adequate funding of Nigerian police force by government to fight kidnapping in Nigeria despite the fact that adequate funding has great impact on the performance of the police in relation to reducing kidnapping. 
The study concludes that underfunding, corruption, poor salary and inadequate welfare and training of the Nigerian police in Ubiaja Community, Edo State as perceived by the public promotes unfairness and impartiality in kidnapping cases, discourages team work and commitment, promotes negligence of duties and results inability to cope with the trend of crime associated and follow up incidence of kidnapping, poses serious security threat to the lives of the people, results to lack of skills on how to avoid attack on the Nigerian police force and reduces the professionalism of the police in combating crime. Thus, financing community policing has great impact on the role of the police in curbing kidnapping. Based on these findings, the study recommends the following

i. The police should put machinery in place to rid itself of bad elements within the system that have soiled the image of the police with extortion, demanding and taking of bribe from the public.

ii. The Police should also embark on the laundering of its image by rebranding. The media can readily be used in this direction, if it genuinely desires a better image and service delivery.

iii. Non-governmental organizations and the government can help to reduce the crime of kidnapping by organizing workshops and seminars for parents, which will guide them in modeling youths to be disciplined and useful to the society.

iv. Religious leaders can make their own contributions through their teachings by instructing parents on the need to guide the youths in their custody to achieve better skills.

v. There is the need for government to be alive to its responsibility of adequately funding the police, instead of paying lip service to their welfare. In this direction, there should be training and retraining of officers and men of the police in line with modern dictates.

vi. Government should organize special trainings for them on how to identify victims of kidnapping and be able to take them from the kidnappers without them being hurt.

\section{Conflict of Interest}

There is no conflict of interest.

\section{References}

[1] Beland, D. (2005). The political construction of collective insecurity: From moral panic to blame avoidance and organised responsibility. Centre for European Studies Working Paper.

[2] Obarisiagbon, E. I. (2017). Kidnapping and the administration of criminal justice in selected states in Nigeria Unpublished Ph.D dissertation, University of Ibadan, Ibadan, Nigeria.

[3] Abraham, U. E. (2010). The social problem of kidnapping and its implication on the socio-economic development: A case study of Uyo Metropolis. A Master's Degree Thesis, Department of Sociology and Anthropology, University of Uyo, Nigeria.

[4] Davidson, I. (2010) Nigeria: Stunting Economic Growth and Development in South East (THISDAY13 June 2010).

[5] Tzanelli, R. (2006). Capitalizing on value: Towards a sociological understanding of kidnapping. Sociology 40: 929947. http://soc.sagepub.com

[6] Inyang, J. D. (2009). Kidnapping: who can deliver Nigeria? News D or Magazine. Vol. 1 (a): July 12 p11-15.

[7] Okarah, C. I. (2014). Cause of insecurity in Nigeria: The challenges and relevance of the Nigeria Police Force as a panacea. Unpublished M.sc Thesis, University of Nsukka.

[8] Criminal Code Act, Cap C 38 Laws of the Federation of Nigeria. 2004.

[9] Yang, S. L., and Huang, S. L. (2007) Kwanppi - Taiwan, the significance of geographic proximity improvisation and fluidity. International Journal of Offenders, 51 (3) 324-333.

[10] Alemika, E. E. (2003). The politics of identities and democracy in Nigeria, Jos: University of Jos.

[11] Police Act Laws of the Federation of Nigeria, 2004

[12] Etannibi, E. Alemika, E. and Innocent, C. (2009). The poor and informal policing in Nigeria: A report on poor peoples' perception and priorities on safety, security and informal policing AJ2 focal states in Nigeria. Centre for Law Enforcement Education (CLEEN) Lagos.

[13] Inyang, J. D. and Ubong, E. A. (2013). "The social problem of kidnapping and its implications on the socio-economic development of Nigeria: A study of Uyo Metropolis". Mediterranean Journal of Social Sciences. Vol. 4 No. 6, pp.

[14] Odekunle, F. (2014). Overview of policing in Nigeria: problems and suggestions. Ikeja-Lagos: Cleen foundation.

[15] Ugwuoke, C. U. (2011). Nigeria and the menace of kidnapping: The way forward. The Nigerian Journal of Research and Production, Vol. 18 pp. 44-57.

[16] Adibe, J. (2009). Pervasive kidnapping in Nigeria: symptom of a failing state. Retrieved from http://www.holleafrica.com/showArticles.php?artld=304 \&catld $=1$

[17] Nwadiorah, C. E. and Nkwocha, I. B. (2011). "Kidnapping for Ransom: A prevalent urban Pandemic in Nigeria". Research Journal of Peace and Conflict Studies. I (1) 172-185.

[18] Igbo, E. U. M. (2007). Introduction to Criminology. Nsukka: University of Nigeria Press.

[19] Diara, B. C. D. (2010). "Kidnapping for ransom in Nigeria as revolutionary effect of capitalism in Africa". International journal of research in Arts and social sciences. 2 49-57.

[20] Thom-Otuya, B. E. N. (2010). Kidnapping: "A challenge to Nigeria security system". International Journal of Social Science, Vol. 2. No. 8, pp. 107-116.

[21] Arewa, J. A. (2013). Core national values as determinant of national security and panacea for the crime of kidnapping and abduction in Nigeria. Nigerian Institute of Advanced Legal Studies, Lagos, Nigeria. 
[22] Essien, A. M. and Ema, E. B. (2013). The socio-religious perspective of kidnapping and democratic sustainability in Akwa Ibom State. International Journal of Humanities and Social Science. Vol. 3 N. 4.

[23] Hino, H. (2005). Nigeria Washington D. C., International Monetary fund, 4-84.

[24] Achumba, I. C., Ighomereho, O. S. and Akpor-Robaro, M. O. M. (2013). Security challenges in Nigeria and the implications for business activities and sustainable development. Journal of Economics and Sustainable Development. Vol. 4, No. 2, pp 121.

[25] Adegoke, N. (2014) The Nigeria Police and the challenges of security in Nigeria. Review of Public Administration and Management. Volume 3 No 6. pp 21-36.
[26] Ibeanu, O. (2006). "Conceptualizing Peace" in Best, Shedrack Gaya (Ed) Introduction to Peace and Conflict Studies in West Africa. Ibadan: Spectrum, pp. 3-14.

[27] Randy, S. (2010). Social disorganisation theory. Review of the roots of youth violence. Retrieved May 122012 from www.sagepub.com/upm-data/36812-5.pdf

[28] Obarisiagbon, EI and Omagie, M (2018) Public Perception of the Role of the Nigeria Police Force in Curbing the Menace of Kidnapping in Benin Metropolis, Southern Nigeria: A Criminological Study: Academic Journal of Interdisciplinary Studies: Vol 7 No 1; pp 65-72.

[29] Onyeozili, E. C. (2005) Obstacles To Effective Policing In Nigeria, African Journal Of African Journal of Criminology and Justice Studies. Vol. 1, No. 1. 